\title{
IMPLEMENTATION OF EU WATER POLICY IN UKRAINE: PROBLEMS AND PERSPECTIVES
}

Liudmyla GOLOVKO, Department of International Law and Comparative Law, National University of Life and Environmental Sciences of Ukraine, Heroiv Oborony Street, 15, Kiev, Ukraine, liudmylagolovko10@ gmail.com

\begin{abstract}
The use, protection and management of water resources belong to the most urgent among global environmental problems of our time. Today, the civilization clearly realizes the need for careful management of water resources, maintaining and restoring its quality. Water quality determines the possibility of its use in various fields of human activity. For Ukraine problems of water sector are also acute and urgent. Low efficiency of water use, poor drinking water quality, nitrate contamination of water resources, poor condition of water bodies in Ukraine require more foreign experience in this sphere, especially the EU experience.

The purpose of our scholarly work is to explore actual problems of harmonization of water legislation of Ukraine with the requirements of EU water policy and development of proposals for the improvement of Ukrainian legislation. Main features of harmonization of Ukrainian legislation in the water resources management sphere with EU law and prospects for implementation of principles of EU Water Framework Directive were analyzed. As a result of the study the ways of implementation of positive foreign experience of water objects management in Ukraine are considered.

Considering the scale of ecological crisis in Ukraine the necessity of forming a new system of economic regulators of nature is obvious. Such system must not only accumulate funds for urgent actions, but primarily encourage economic entities to protect the natural environment. We consider it appropriate to introduce mandatory environmental insurance for operators of environmentally hazardous activities.
\end{abstract}

Keywords: EU water policy, water legislation, water management, water quality, water resources

\section{INTRODUCTION}

Modern water management and environmental problems have not only national, but also international significance, became one of the main factors of national security of Ukraine. Environmentally unbalanced economic activities that use significant water resources for the needs of the production sector and cause water pollution, artificial alteration of natural regime of water objects led to degradation processes that began to prevail over self-renewable and self-cleaning ability of water systems. Introduction of provisions of the Water Framework Directive in Ukraine can make the management of water resources more efficient and achieve "good water status" for all water.

Today it is clear that the availability of water resources is one of the most important preconditions for the existence, sustainable development of society. Water is needed in all areas of life: food production, energy production, industrial production and domestic water consumption. The World Bank estimates that in the next 50 years (from the middle of the $21 \mathrm{st}$ century) $40 \%$ of the population will experience water shortage, $20 \%$ will suffer from its lack (The World Bank information..., 2017). This means that maintaining such rate of water consumption as in the second half of the XX century is not possible.

Positive solution of problems, regarding the quality of water resources, depends on the implementation of effective mechanisms of legal support of sustainable use and protection from pollution and depletion of water resources. The European Union pays a special attention to the development and implementation of measures ensuring the quality of water resources is guaranteed.

The object of the research: results of the implementation of EU water policy in Ukraine.

The aim of the research: to carry out the analysis of main trends of development and features of harmonization of Ukrainian water legislation with EU law.

Tasks of the research: to identify problems of harmonization of water legislation of Ukraine with the requirements of EU water policy as well as to give recommendations for future development of Ukrainian water legislation.

\section{METHODOLOGY OF THE RESEARCH}

Legislation and literature on EU water policy was analyzed to compare implementation of the Water Framework Directive in Ukraine and EU member states. We identified three basic parameters as the basis for comparison: river basin management, water resource planning, public participation. The extent of transformation of water governance in Ukraine 
and EU countries was examined, focusing mainly on new EU member states. The methods of comparative, analytical, statistical and logical analysis were used. Based on comparison analysis differences and common problems of implementation of EU water policy in Ukraine and EU member states were determined and recommendations for implementation of successful experience of EU countries in Ukraine were made.

Taking part in the project 575523-EPP-1-2016-1-UAEPPJMO-MODULE "EU Environmental Policy and Law" we have studied European standards in the field of water resources quality, found some gaps in Ukrainian legislation and filled them in. As a result of the study draft law "On prevention and elimination of damage caused to the environment" was elaborated.

\section{RESULTS}

\section{Directions of Implementation of Provisions of the Water Framework Directive in Ukraine}

Ukraine belongs to countries with a relatively low water resources. The average perennial renewable volume of surface water is approximately $95 \mathrm{~km} 3$ per year, which is equivalent to 2,0 thousand $\mathrm{m}^{3}$ per person. In the low-water years the average perennial renewable volume of surface water is approximately 1.2 thousand $\mathrm{m}^{3}$ per person, which, according to UNESCO classification, characterizes Ukraine as a water insecure country. Water scarcity is observed almost everywhere, especially in the basins of the Lower Dnieper, Seversky Donets, Southern Bug, Ingul and Azov rivers (Hadzalo, 2015, pp. 5).

The assessment of the situation in Ukraine identified the following main problems of the water policy: natural shortage of water resources, as well as their uneven distribution across the territory and in time; depletion of water resources due to the large volume of water intake for economic needs; significant amount of pollutants entering the river due to discharges and flat-flush; excessive regulation of river runoff, which causes additional water loss for evaporation, slowing down of water exchange and, consequently, deterioration of water quality and riverbed degradation; large volume of water losses during transportation in water supply networks and irrigation systems (approximately 33 percent). To a large extent, water problems are also caused by deficiencies in public relations, namely: imperfection of the existing system of public administration in the sphere of use, protection and restoration of water resources, lack of clear delineation of water protection and water management functions; lack of effective economic mechanisms for stimulating rational water use; lack of awareness and low level of ecological culture of the population; the slow implementation of positive foreign experience in the sphere of water use and water protection. That is why implementation of the Directive 2000/60/EC of the European Parliament and of the Council of 23 October 2000 establishing a framework for Community action in the field of water policy (EU Water Framework Directive) in Ukraine is extremely important.

Implementation of EU water policy in Ukraine demands obligatory coordination of organizational, economic and legal aspects of governance that is crucial for its effective functioning. According to the Action plan for the implementation of the Association Agreement between Ukraine, on the one hand, and the European Union and the European Atomic Energy Community and their Member States, on the other hand, State Water Resources Agency of Ukraine is responsible for implementation of the Directive № 2006/60/EC. In order to meet the requirements of the Water Framework Directive in Ukraine the following measures should be taken: the adoption of national legislation and the appointment of an authorized body (bodies); to define the term "hydrographic zoning of Ukraine" at the legislative level; development of provisions on basin agency with imposing on it functions under Article 3 of the Directive; determination of river basin districts and mechanisms of management of international rivers, lakes and coastal zones; analysis of the characteristics of river basin districts; implementation of water quality monitoring programs; preparation of river basin management plans, public consultation and publication of these plans (Vitiv, 2015).

Ukrainian legislation in the sphere of water relations is characterized by the presence of a codified legal act, namely the Water Code of Ukraine of June 6, 1995 № 214/95-VR, which is one of the key documents in this area. In addition a number of national programs in water sector were adopted: National Program of Environmental Rehabilitation of the Dnieper River Basin and Improvement of the Quality of Drinking Water of February 27, 1997 № 123/97-VR; Law of Ukraine “On the National Program of Adaptation of Ukrainian Legislation to the EU Law” of March 18, 2004 № 1629-IV; Law of Ukraine "On approval of the National target program for the development of water management and ecological improvement of the Dnipro river basin until 2021” of May 24, 2012 № 4836-VI; Decree of the President of Ukraine “On Approval of the Strategy of Ukraine's Integration into the European Union” of June 11, 1998 № 615/98; Law of Ukraine “On the Fundamentals (Strategy) of the State Environmental Policy of Ukraine until 2020” of December 28, 2010 № 2818-VI.

Ukraine's legislation partly complies with the EU Water Framework Directive. One of the crucial principles of European water policy - the principle of river basin management is enshrined in the Water Code of Ukraine and some other legislative acts. Water Code of Ukraine states that management of water resources should be based on the basin principle, but at the same time there is no clear strategy for implementation of this principle in the form of a plan with defined deadlines. In Ukraine the transition from the administrative-territorial to basin water management needs improvement of legislation primarily in terms of establishment of law aimed at practical implementation of integrated water management by basin principle, such as the definition of key terms, hydrographic and water management division of the territory of Ukraine, credentials of the state administration and local government and so on.

EU member states have plans with defined deadlines for implementation of Water Framework Directive. However, fifteen years after the Water Framework Directive was introduced, achieving its objectives remains a challenge, with $47 \%$ of EU surface waters not reaching the good ecological status in 2015-a central objective of EU water legislation. During the first Water Framework Directive cycle, which operated from 2009 to 2015, the number of surface water bodies in 
"good" state only increased by $10 \%$. This has led to the Directive's effectiveness as a policy tool being questioned; with many reviews further highlighting drawbacks and weaknesses (Voulvoulis, 2017).

Another significant problem in Ukraine is that the system of river financing is imperfect: the funds obtained from water users and polluters at the local level are accumulated in the center and minimum resources are returned to the basin departments, which reduces their financial possibilities. The main reason for failure to comply with primary environmental protection measures is the underfunding of budget programs. For example, Ostap Semerak, Minister of Ecology and Natural Resources of Ukraine states that there is a state program aimed at clearing the riverbeds. The funding of this program is 200 thousand hryvnia per year. The amount has not changed during three years and next year it will be the same. According to the minister, such funding is not enough to work out even one project (Ukraine turns to desert?, 2017). Contrary to Ukraine, in EU member states river basin authorities are equipped with extensive executive powers and budgets (Moss, 2012).

A further negative fact is that currently in Ukraine no single state agency that would resolve problems of water management, water resources and water supply of the population. The existence of an extensive system of governing bodies leads to duplication of functions concerning water supply of the population and rational utilization and water conservation, and this, in turn, does not allow coordinated actions and effective implementation of planned tasks.

In EU member states, as well as in Ukraine there is no single state agency that is responsible for implementation of water policy. Water governance administration has been decentralized and/or devolved (Jaspers, 2003). The decentralized nature of directive implementation allows member states flexibility in developing scale-specific water management policy (Green et al., 2013). Water Framework Directive provides flexibility for developing water policy at the appropriate level, because geophysical circumstances differ per region (Keessen et al., 2010).

In some EU countries, like in Ukraine, there is a duplication of authority between different bodies. For example, in Poland, the Ministry of Environment is responsible for water management in the country. Water management is organized according to river basins. Further decentralization of water management is not discussed yet. Within the administration structure the coordination of water management is realized by the President of National Water Management Authority. The National Water Management Authority operates within the framework of the Ministry of Environment and its President reports to the Minister of Environment. However, many water related issues are outside the responsibility of the president. Ministry of Infrastructure is responsible for inland water transportation; Ministry of Agriculture and Rural Development and the regional governments are responsible for dikes and for melioration infrastructure; the National Water Management Authority shares the responsibility for water permits with county governments and regional representatives of the central government. Water management infrastructure of cultural and historic value is under the responsibility of the Ministry of Culture. Moreover, outside the realm of the National Water Management Authority is the crisis management including floods and droughts, which are under the ministry of Internal Affairs and Administration. Lack of integration is especially visible in case of extreme events. Despite substantial investments, losses in infrastructure caused by the two great floods, of 1997 and 2001 were not completely repaired. The main reason is the lack of financial resources but also diffusion of responsibility between central and local and regional governments (Kowalczak, 2013).

In Ukraine most of the laws on economic activities provide compensation for damage due to environmental pollution, but they are not sufficient to ensure the prevention and elimination of damage caused to the environment including water resources. In order to adapt domestic legislation to the European legislation on environmental protection and Directive 2004/35/CE of the European Parliament and of the Council "On environmental liability with regard to the prevention and remedying of environmental damage" of 21 April 2004 in particular, in our opinion, it is necessary to adopt in Ukraine the Law "On prevention and elimination of damage caused to the environment". The law should define a) the rights and obligations of business entities, which activity is highly hazardous, in the sphere of prevention and elimination of environmental damage, b) the role of public authorities in the sphere of prevention and elimination of environmental damage, c) liability for breach of duties under this law. The adoption of an act on the prevention of damage to the environment corresponds to the practice of EU member states.

The Law of Ukraine "On the prevention and elimination of environmental damage" should include provisions, which would enable the public to influence decisions concerning the necessary preventive measures. Non-governmental organizations working at the environmental protection and persons who suffered the adverse effects or are able to experience the damage from environmentally hazardous activities should have the right to require the competent authority to take the necessary preventive measures. This requirement is necessary because in Ukraine the public has actually no real impact on the environmentally significant decisions.

In the legislation of the EU member states, the difference between the roles of the general public and key stakeholders is not emphasized. Therefore, the formalized public participation only contains the provision of information to the public and receiving consultations which must be dealt with officially. Higher levels of participation (such as involvement or cooperation) are recommended in the guidelines issued by ministries (for example, Czech Republic), but they are not obligatory to the competent authorities (Kowalczak, 2013). In in this sphere we can see problems similar to those which exist in Ukraine.

\section{Drinking water quality standards in Ukraine and their compliance with the EU standards}

Human right to drinking water is considered as one of essential human rights without which human existence is not possible. The right to drinking water stands alongside with other fundamental rights, such as the right to life and the right to food (Ladychenko, 2015). Based on this there is a need for further analysis and improvement of public policy and 
legislation of Ukraine in the field of drinking water and drinking water supply as means of ensuring human right to safe drinking water in the context of security of the state as a whole and its citizens.

The Law of Ukraine "On Drinking Water and Drinking Water Supply" reflects basic principles of the state policy in the field of drinking water, namely convergence of national standards of drinking water quality and evaluation methods to appropriate standards and methods that are used in the European Union. However provisions of this law are mainly declarative, does not contain the terms for achieving quantitative and qualitative results. Therefore it is difficult to assess how the legislation is implemented in practice.

Adopted in Ukraine State standards 2.2.4-171-10 "Hygienic requirements for drinking water intended for human consumption" were designed to meet the requirements of Council Directive 98/83/EC of 3 November 1998 on the quality of water intended for human consumption. This regulatory document is binding and has expanded the list of indicators of epidemiological safety of drinking water, sanitary-chemical indicators of its quality, determines the degree of microbiological, parasitological and viral contamination of water, as well as the maximum allowable concentration for a number of toxic compounds. At the same time it should be noted that the above mentioned state standards are not implemented due to lack of instrument base in laboratories and state methods of conducting the researches. Only two laboratories across the country can perform declared in the document research (Cherkashina, 2013). So there are differences between the new standards of quality of drinking water in Ukraine, which are even stricter than European, and technical capacity of many water utilities to conduct appropriate testing.

Requirements of the article 13 of the Council Directive 98/83/EC concerning measures necessary to ensure that adequate and up-to-date information on the quality of water intended for human consumption is available to consumers also is not implemented in practice, although are provided by Article 9 of the Law of Ukraine "On Drinking Water and Drinking Water Supply" and by Order of preparation and publication of national reports on water quality and state of drinking water in Ukraine, approved by the Cabinet of Ministers of Ukraine of 29.04.2004, № 576. At the same time citizens should be aware of the state of drinking water (Funta, 2014).

Solving problems related to water supply requires a set of measures in order to update and modernize the network of water supply and sewage system, introduction of rational norms of water consumption for the population, improvement of accounting of water resources and tariff policy that could revive water supply of population, create the basis for stabilization of water use and improvement of water quality.

Unlike in Ukraine, in new EU member states significant water quality improvement occurred in the 1990s, and significant development occurred, especially in terms of significant investments into hundreds of public sewage treatment plants. The quality of drinking water available to consumers in these European countries has improved in recent years thanks to EU funding, but a significant amount of money still needs to be invested, according to a new report from the European Court of Auditors (European Court of Auditors, 2017). Synthesis report on the quality of drinking water in the Union examining Member States' reports for the 2011-2013 period, foreseen under Article 13(5) of Directive 98/83/EC shows that compliance rates for parameters directly reflecting the quality of the drinking water supplied to consumers reached with one exemption at least $99 \%$ for the first time in all member states during the 2011-2013 reporting period. This is a positive achievement that reflects the efforts made by all concerned for the correct implementation of the Drinking Water Directive (European Commission..., 2016).

\section{Prevention of Water Pollution due to Runoff of Nitrates from agricultural lands}

Nitrate contamination of water sources, eutrophication and related threats today are relevant to society. For river waters of Ukraine very high level of pollution with mineral forms of nitrogen is distinctive. General viewing during the last 10 years showed decreasing of levels of nitrogen pollution but it is still quite high (Riabec, 2011). Increasing of mineral nitrogen in the Azov sea area is observed. There is some increasing in contents of pesticide pollution in the Black Sea for chlorine-organic compounds (Moniushko, 2015).

Currently provisions of the Directive 91/676/EEC concerning the protection of waters against pollution caused by nitrates from agricultural sources (the Nitrates Directive) are not implemented in the national legislation of Ukraine. According to the Law of Ukraine "On the Fundamentals (Strategy) of the State Environmental Policy of Ukraine until 2020 ” of 21 December 2010 № 2818-VI issues related to prevention of water pollution due to runoff of nitrates from agricultural lands is one of the priority areas of harmonization of Ukrainian environmental legislation with the provisions of EU law. At the same time, it should be noted that implementation of the Directive should not be perceived only as a technical task (just as adoption of specific legislative norms). The main tasks in the sphere of implementation of the Nitrates Directive are as follows: adoption of national legislation and determination of the authorized body (bodies); determination of zones vulnerable to accumulation of nitrates; introduction of action plans for zones vulnerable to accumulation of nitrates; introduction of monitoring programs.

The challenges of the implementation of the Nitrates Directive should also be assessed. Compliance with European environmental requirements in the field of storage and use of organic fertilizers will be problematic for agricultural producers because of their relatively low level of environmental awareness and limited own funds to finance the necessary measures. The Nitrates directive in Ukraine concerns 3,500 agricultural enterprises (half of them have farms with 100 to 1,000 head of cattle) and 1.3 million rural households (one third of them have 2-4 or more heads of large horned cattle). They must be equipped with special impermeable containers and storage areas for manure in the absence of own funds and limited sources of financial resources, because banks tend to refuse to provide loans to agricultural producers for these purposes. Therefore, it is necessary, in parallel with the implementation of the Nitrates Directive norms in national legislation, to create educational courses, a web resource, to intensify the counseling service in order to improve the level 
of thematic education of agricultural producers. It is advisable to provide them with budget support for the construction of organic fertilizer storage facilities, the purchase of vehicles and mechanisms for their proper placement in areas vulnerable to nitrate pollution. For example, in Latvia, these costs were financed from the state budget for approximately $50 \%$, and at the same time not all agricultural producers coped with the necessary work during the transitional period (Ecological innovations..., 2016).

The European Union has formed an extensive network of monitoring of groundwater pollution caused by nitrates from agricultural sources, which gave the possibility to identify the source of getting nitrogen compounds and choose the methods of its localization. Ukraine should use this experience.

According to V. Holian, O. Sakal et al, with whom we should agree, at the regional level there should be established working groups with representatives of the Department of agricultural development of regional administrations, NGOs, regional units of the State science and technology center for protection of soil fertility, State service of Ukraine for geodesy, cartography and cadaster, State water resources agency of Ukraine with the goal to develop a roadmap for the implementation of Directive 91/676/EEC (Holian et al., 2015). This is necessary because due to the significant number of households engaged in agricultural production and their fragmentation many problems concerning development of measures for formation of system for monitoring of discharges of nitrogen compounds into the water will arise.

EU member countries have much more progress in the implementation of the Nitrates Directive. Vulnerable zones have been already determined. The mandatory measures of the Nitrates Directive are difficult to implement systematically throughout the territory, especially when it is vast. The measures are therefore systematically adapted not as a general rule but in their local or cyclical implementation. Therefore, many points are added to the regulations of each country in order to adapt to the climate, to the farming methods and to crop conditions, but also sometimes to the magnitude of the risks for water quality due to certain practices. Moreover, in Denmark, the Netherlands, Belgium (Flanders), the calculation and control of the fertilization balance are based on operational integrated information systems sometimes directly filled in online by stakeholders. These information systems provide very accurate knowledge about practices and fertilizer flows. Common Agricultural Policy data (crop types and surfaces), livestock identification data, possibly completed with mandatory declarations, and remote declarations of land application logbooks, transportation of fertilizing elements, and soil analyses, are grouped in this way. Through systematic cross-checking of the information, these data help to produce budgets during and at the end of campaigns, constitute the basis for warning or advising farmers and are used to better target on-site controls. (Analysis of implementation..., 2015).

\section{CONCLUSIONS}

Ukraine's legislation partly complies with the EU Water Framework Directive. One of the crucial principles of European water policy - the principle of river basin management is enshrined in the Water Code of Ukraine and some other legislative acts, but at the same time there is no clear strategy for implementation of this principle in the form of a plan with defined deadlines and basin authorities, which has already been created, do not have enough powers to exercise their functions. Unlike in Ukraine, in EU member states the principle of river basin management was not only established in the legislation, but also implemented in practice. In EU member states river basin authorities are equipped with extensive executive powers and budgets.

In EU member states, as well as in Ukraine there is no single state agency that is responsible for implementation of water policy. Water governance administration has been decentralized and/or devolved. The decentralized nature of directive implementation allows member states flexibility in developing scale-specific water management policy. In some EU countries, like in Ukraine, there is a duplication of authority between different bodies involved in water management, which is a problem that needs to be addressed.

On the example of EU countries in Ukraine the following measures should be taken in order to adapt Ukrainian legislation to the EU Water Framework Directive: inclusion in the Water Code of Ukraine provisions on river basin management plans which should comply with article 11 of the Directive; development of river basin management plans; development of the system of water-related issues monitoring; development and fixing in the legal framework assessment criteria of the river basin; adoption and implementation of provisions of the Directive concerning public information and consultation.

In Ukraine the public has actually no real impact on the environmentally significant decisions. In EU member states citizens have mainly right to information and consultations. Higher levels of participation (such as involvement or cooperation) are recommended in the guidelines issued by ministries, but they are not obligatory to the competent authorities. Here there are perspectives for further development, because public participation may contribute to a more informed planning process.

At legislative level quality standards for drinking water in Ukraine meet the standards of drinking water quality in the EU, but they are not fulfilled in practice. In addition to amendments to the water legislation, there are a number of tasks that must be completed: implementation of comprehensive measures intended to modernize and upgrade the water supply and sewage network, the introduction of rational water consumption standards for the population, improvement of water resources accounting, improvement of tariff policy, creation of a basis for stabilization of water use and improvement of quality of water intended for human consumption.

Unlike in Ukraine, in EU countries significant water quality improvement occurred. The quality of drinking water available to consumers in new EU member states has improved in recent years thanks to EU funding. According to last Synthesis report of the European Commission on the quality of drinking water in the Union compliance rates for parameters directly reflecting the quality of the drinking water supplied to consumers reached with one exemption at least 
$99 \%$ for the first time in all member states. This is a positive achievement that reflects the efforts made by all concerned for the correct implementation of the Drinking Water Directive. Without external financial support similar improvements in the sphere of drinking water supply in Ukraine cannot be achieved.

In contrast to EU legislation, provisions of Ukrainian legislation are not sufficient to ensure the prevention and elimination of damage caused to water resources and must be improved. In particular, Law "On prevention and elimination of damage caused to the environment" should be adopted.

Taking into account high level of domestic pollution of surface and groundwater with chemicals and nitrates through the use of fertilizers on steep slopes and near water bodies implementation of the EU Nitrates Directive is a necessary condition for sustainable land use and preservation of quality of water resources. At the same time, it should be noted, that it is expected that the majority of the smaller farmers in Ukraine will never acquire proper manure storage facilities. Due to their uncertain future they are not targeted to comply with the Nitrates Directive. On the example of EU member states in Ukraine it is necessary to develop and implement strategy for implementing the Nitrates Directive, research and development programs for farmers (which are developed and implemented almost in all EU countries).

\section{REFERENCES}

1. Analysis of implementation of the Nitrates Directive by other Member States of the European Union. 2015 . Available at http://www.carteau-rdi.fr/contenu/actualites/analysis_implementation_nitrates_directive_other_member_states_european_union_ger

2. Cherkashina, M., Vystavna, Y. 2013. Legislative aspects of water pollution in Ukraine and European Union: comparison of the principal determinants. Journal of Kharkov National University named after V.N. Karazin, Series “Law” 1062, pp. $238-242$.

3. Ecological innovations of the implementation of the Common Agricultural Policy in Ukraine: a scientific and analytical note. 2016, 1st ed., Institute of Economics and Forecasting of NASU, Kiev.

4. European Commission. 2016. Synthesis Report on the Quality of Drinking Water in the Union examining Member States' reports for the 2011-2013 period, foreseen under Article 13(5) of Directive 98/83/EC. Available at http://ec.europa.eu/environment/water/water-drink/pdf/reports/EN.pdf

5. European Court of Auditors. 2017. Bulgaria, Hungary, Romania water quality improved, but significant funds still needed, say EU Auditors. Available at https://www.eca.europa.eu/Lists/News/NEWS1709 12/INSR DRINKING WATER EN.pdf

6. Funta R., Nebeský, Š., Juriš, F. 2014. Právo európskej únie, Tribun EU, Brno [In Polish]

7. Green, O.O., Garmestani, A.S, Van Rijswick, H.F.M.W., Keessen A.M. 2013. EU water governance: striking the right balance between regulatory flexibility and enforcement? Ecology and Society, Vol. 18, Iss. 2, p. 10. https://doi.org/10.5751/ES-05357180210

8. Hadzalo, J. 2015. Water strategy for the period until 2025, 1st ed., Institute of Water Problems and Melioration of NAAS, Kiev.

9. Holian, V., Sakal, N., Tretyak, N. 2015. Regulation of activity of households in the context of protection of waters from pollution by nitrates from agricultural sources: Ukrainian realities and the possibility of implementing European experience. Agrosvit, Vol. 20, pp. 6-16.

10. Jaspers, F.G. (2003). Institutional arrangements for integrated river basin management. Water policy, Vol. 5(1), pp.77-90.

11. Keessen, A.M., Van Kempen, J.J.H., Van Rijswick, H.F.M.W., Robbe, J., Backes, C.W. 2010. European river basin districts: are they swimming in the same implementation pool? Journal of Environmental Law, Vol. 22, Iss. 2, pp.197-222. https://doi.org/10.1093/jel/eqq003

12. Kowalczak, P., Maczak, P., Slavikova, L. 2013. Institutional Evolution in Water Management in the Czech Republic and Poland. International Journal of Water Governance, No. 1, pp. 307-322. https://doi.org/10.7564/13-IJWG8

13. Ladychenko, V. 2016. Scientific notes of the Institute of Legislation of the Verkhovna Rada of Ukraine 3, pp. 39-43.

14. Moniushko, M. 2015. Evaluation of water quality by hydrochemical indicators for aquatories of the North-Western shelf of the Black Sea. Hydrology, Hydrochemistry and Hydroecology, Vol. 38, pp. 69-77.

15. Moss, T. 2012. Spatial Fit, from Panacea to Practice: Implementing the EU Water Framework Directive. Ecology and Society, Vol. 17, No. 3. http://www.ecologyandsociety.org/vol17/iss3/art2/

16. Riabec, K. 2011. On the Issue of Organizational and Legal Support of Water Quality. Legal Science, Vol. 6, pp. 84-89.

17. The World Bank. 2017. Water. Available at http://www.worldbank.org/en/topic/water/overview

18. Ukraine turns to desert? 2017. Available at http://uain.press/articles/ukrayina-peretvoryuyetsya-na-pustelyu/

19. Vitiv, V. 2015. The state policy in the field of drinking water and water supply in the light of the new doctrine of administrative law. Proceedings of the International Scientific Conference "Legal science: challenges and the present", pp. 69-73, Black Sea Foundation of Law.

20. Voulvoulis, N., Arpon, K.D., Giakoumis, T. 2017. The EU Water Framework Directive: from great expectations to problems with implementation. Science of the Total Environment, Vol. 575, pp. 358-369. https://doi.org/10.1016/j.scitotenv.2016.09.228

21. Zerkalov, D. 2012. Environmental safety and environment, 1st ed., Osnova, Kiev. 